\title{
Influence of algal diet on growth and ingestion of Calanus helgolandicus nauplii
}

\author{
C. Rey $^{1, *}$, R. Harris ${ }^{2}$, X. Irigoien ${ }^{2}$, R. Head ${ }^{2}$, F. Carlotti ${ }^{3}$ \\ ${ }^{1}$ Université P. et M. Curie (Paris VI), Station Zoologique, ESA 7076, CNRS/INSU, BP 28, 06230 Villefranche-sur-mer, France \\ ${ }^{2}$ Plymouth Marine Laboratory, Prospect Place, West Hoe, Plymouth PL1 3DH, United Kingdom \\ ${ }^{3}$ Laboratoire d'Océanographie Biologique, C.N.R.S./Université Bordeaux 1, UMR 5805, 2 rue du Professeur Jolyet,
} 33120 Arcachon, France

\begin{abstract}
Nauplii of Calanus helgolandicus were raised from eggs, laid within a $12 \mathrm{~h}$ period, to Copepodite Stage I (CI) on 5 different species of algae at high concentrations at $15^{\circ} \mathrm{C}$. The diets used were Isochrysis galbana (5 $\mu \mathrm{m}$ spherical diameter), Rhodomonas baltica $(7 \mu \mathrm{m})$, the coccolithophorid Pleurochrysis carterae $(12 \mu \mathrm{m})$, the diatom Thalassiosira weissflogii $(14 \mu \mathrm{m})$ and the dinoflagellate Prorocentrum micans $(30 \mu \mathrm{m})$. Each day a sample was taken and preserved for later cohort analysis. Growth was estimated from CHN samples collected almost daily, from which naupliar stages were also distinguished. Ingestion was measured for each naupliar feeding stage. The fastest development was obtained with I. galbana and P. micans. We found the highest value of carbon and nitrogen content of Naupliar Stages NV to CI for individuals reared on the smallest algae, I. galbana and $R$. baltica. However, ingestion rate in terms of carbon or nitrogen was lowest with these same (smallest) algae. Therefore, the gross growth efficiency was highest for the smallest algae. These results suggest the following: Firstly, that factors influencing development time and weight in stage are different; weight in stage is negatively related to algal size, whereas development time is independent of it. The quality of the algal biochemical components could be the factor influencing development. Secondly, that small algae are fully assimilated in the gut whereas larger cells, i.e. those with indigestible components around the cell (theca, frustule, calcium layer) are only partly assimilated.
\end{abstract}

KEY WORDS: Calanus helgolandicus $\cdot$ Nauplii $\cdot$ Growth $\cdot$ Development $\cdot$ Ingestion $\cdot$ Efficiency $\cdot$ Food quality

\section{INTRODUCTION}

The maintenance of a copepod population in the marine ecosystem depends on its success in producing new recruits. The presence of actively spawning females, the survival of the young recruits, and their successful development in the environment is critical for a species. Environmental factors have a major effect on key parameters of population dynamics such as fecundity, survival and development of both naupliar and copepodite stages. Many laboratory and field

\footnotetext{
*E-mail: catherinerey@aol.com
}

studies have been conducted to estimate the influence of temperature and food on female fecundity (Peterson 1988, Plourde \& Runge 1993, Jónasdóttir 1994, Pond et al. 1996, Hirche et al. 1997) and on the development and the growth of copepodite stages (Paffenhöfer 1976, Vidal 1980a,b, Corkett et al. 1986, Klein Breteler et al. 1990, Peterson \& Painting 1990).

In contrast, nauplii have been less well studied. The major factors relevant to growth and development of nauplii include initial egg characteristics, temperature, food concentration and the type of food consumed by the nauplii. The initial egg characteristics result from the past feeding of the females producing the eggs (Peterson 1986, Guisande \& Harris 1995, Melle 1998). 
Some studies have found consumption of diatoms by females to result in low hatching success (Ianora \& Poulet 1993, Poulet et al. 1994, 1995, Laabir et al. 1995, Chaudron et al. 1996, Ban et al. 1997), but this is still open to discussion (Jónasdóttir \& Kiørboe 1996, Jónasdóttir et al. 1998, Irigoien et al. 2000b).

Development, body size and weight of nauplii and copepodites have been negatively related to temperature (Thompson 1982, Peterson 1986, Hopcroft \& Roff 1998). Ontogenetic differences in the physiological response to temperature in copepods have also been noted (Pedersen \& Tande 1992). The effect of food quantity on growth processes has often been unclear (Hart 1990, Hopcroft \& Roff 1998), but some studies have clearly established an effect of food limitation on wild nauplii (Lopez 1991, Melle 1998), and this has been further substantiated by laboratory studies (Green et al. 1991, Klein Breteler \& Schogt 1994, Lopez 1996).

Food quality is another factor which has to be considered when examining variability in naupliar growth (Mullin \& Brooks 1970, Paffenhöfer 1971, 1976, Fernández 1979a,b, Diel \& Klein Breteler 1986, Verity $\&$ Smayda 1989). The major algal characteristics of importance are biochemical content, morphology, and digestibility of the algae (e.g. presence of indigestible thecae or frustules around the cell). This raises the question of whether differences in growth and development of nauplii are due to differences in food quality.

The aim of this study was to measure development, growth and ingestion rates and therefore gross growth efficiency of Calanus helgolandicus nauplii, a key copepod species of the North Atlantic marine ecosystems, fed on different algal diets and to compare these results with some characteristics of nauplii collected in the field. Experiments were performed at high food concentrations so that the nauplii were not affected by quantitative food limitation.

\section{METHODS}

Experimental set-up. Calanus helgolandicus females were sorted from freshly collected samples from a coastal station (Stn L4: 50 $15^{\prime} \mathrm{N}, 4^{\circ} 13^{\prime} \mathrm{W}, \sim 10 \mathrm{~km}$ off Plymouth, western English Channel). Between 400 and 600 females were placed in several 2.51 Plexiglas cylinders with a $400 \mu \mathrm{m}$ mesh false bottom, suspended in 41 beakers filled with $0.8 \mu \mathrm{m}$ filtered sea water and maintained at $15 \pm 1^{\circ} \mathrm{C}$. A mixture of different phytoplankton species (Isochrysis galbana, Prorocentrum micans and Thalassiosira weissflogii) was supplied daily in order to provide optimal food conditions for female egg production. One to $3 \mathrm{~d}$ later (at $\sim 21: 00 \mathrm{~h}$ ), cylinders containing the females were transferred to a new beaker filled with a fresh algal solution. Twelve hours after that, the eggs were removed and 7 batches of 500 eggs each were prepared and separately transferred into $2 \mathrm{l}$ glass bottles. For each phytoplankton species tested, 7 bottles containing 500 eggs each were filled with filtered sea water and a known algal concentration. An eighth bottle, filled in the same way but without copepods, was used as a control. Before sealing the bottles, they were covered by a transparent plastic film in order to exclude bubbles from the water. Finally, the 8 bottles were placed in a cold room at $15 \pm$ $1^{\circ} \mathrm{C}$ under an 18/06 h light/dark cycle and fixed to a rotating wheel $(0.5 \mathrm{rpm})$ maintaining the algae in suspension. This procedure was carried out at different times of the year to test each of the 5 algae.

Phytoplankton species. Experiments were carried out successively with 5 different algal species in the exponential growth stage and covering a wide range of cell diameters (Table 1): the prymnesiophyte Isochrysis galbana (4.6 $\mu \mathrm{m}$ equivalent spherical diameter, ESD), the cryptophyte Rhodomonas baltica (7.5 $\mu \mathrm{m}$ ESD), the coccolithophore Pleurochrysis carterae (9.6 $\mu \mathrm{m}$ ESD), the diatom Thalassiosira weissflogii (13.1 $\mu \mathrm{m}$ ESD) and the dinoflagellate Prorocentrum micans (26.6 $\mu \mathrm{m}$ ESD). Unialgal cultures, obtained from the Plymouth Culture Collection, were grown at $15^{\circ} \mathrm{C}$ in 2.51 Erlenmeyer flasks using 'f/2' medium (Guillard 1975). Cultures were incubated under a 12/12 h light/dark cycle at average light intensities of $100 \mu \mathrm{E} \mathrm{m}^{-2} \mathrm{~s}^{-1}$. The batch cultures were harvested in the exponential growth phase, as indicated by cell counts using a Coulter Multisizer, and exponentially growing cultures were diluted daily with fresh medium. The algal concentration of each experiment was initially greater than $360 \mu \mathrm{gC} \mathrm{l}^{-1}$, i.e. a high food level characterising a phytoplankton bloom. This high food level ensured that the influence of the qualitative food supply on naupliar development rather than quantitative effects, was investigated. Cell carbon and nitrogen contents were measured from aliquots of predetermined cell concentration collected at the start of each experiment. The algal sample was filtered onto ashed glass-fibre filters (Whatman, GF/F) and stored at $-25^{\circ} \mathrm{C}$ for later analyses with a CarloErba Elemental Analyser, Model NA1500. Three cell counts were taken daily from a sample collected from each bottle with a Coulter Multisizer, fitted with a $100 \mu \mathrm{m}$ orifice tube. For the non-feeding stages (eggs to Nauplius II), a dilution of the algal suspension in each bottle was required to compensate for algal growth. For the feeding naupliar stages, the amount of cells removed by grazing was replaced in each bottle by an equal amount of fresh phytoplankton culture.

Cohort development. Every morning ( 09:30 h), a sub-sample of around 30 living individuals was collected from a bottle. This was done after gently mixing the water and then siphoning a sub-sample of the water con- 
taining the copepods via a tube placed in the middle of the bottle. Sub-samples were taken from a different bottle each day to ensure that the individual concentration per bottle decreased as synchronously as possible. The copepods were preserved in $4 \%$ borax-buffered formaldehyde for later cohort analysis. Stage duration was estimated from cumulative frequencies of individuals using the method of 'median development time' (Peterson \& Painting 1990) without any data transformation. The initial time $t=0$ was defined as the time when $50 \%$ of eggs were spawned, assuming that the eggs used for initiating experiments were uniformly spawned by females during the $12 \mathrm{~h}$ period after their collection.

Length measurements. The length of nauplii was measured on individuals from the preserved samples under a microscope. Thirty individuals of each stage from eggs to Copepodite Stage I (CI) were selected for these measurements, except in some experiments where the individual number available for 1 stage (i.e. for Nauplius Stages I and II and CI) was lower. Because the body of Nauplius Stages III to VI is curved, 2 measures were registered for all nauplii, the first from the top of the head to the bottom of the cephalosome and the second from the bottom of the cephalosome to the bottom of the naupliar body. These measurements added together constitute the total length of the nauplius. For Stage CI, the cephalothorax length was measured. The average length from hatching to $\mathrm{CI}$ for each experiment was compared using a non-parametric Kruskal-Wallis test followed by a multiple comparison test (Scherrer 1984). All statistical analyses were conducted with SYSTAT 7.0 (SPSS Inc., Chicago).

Carbon and nitrogen content. For each experiment, samples for CHN analysis were taken almost every day from a different bottle. Individuals required for the $\mathrm{CHN}$ analysis were gently regrouped by stage using a pipette except for Stages NI and NII, which were not distinguished. Copepods were carefully counted and rinsed twice in filtered sea water to remove any algae from the incubation medium. Finally, individuals were pipetted onto $21 \mathrm{~mm}$ GF/F glass-fibre filters and stored at $-25^{\circ} \mathrm{C}$ until later analysis with a Carlo-Erba Elemental Analyser. The number of individuals required per sample was 200 for eggs, 150 to 200 for NI or NII, 90 for NIII, 60 for NIV, 45 for NV, 30 for NVI and 20 for CI. The number of replicates per day for any given stage varied with experiments, and was low for the young stages; this prevented a complete statistical analysis on all stages between the different experiments. More replicates were run for Stage NVI because the potential differences between the NVI weights obtained with different algal diets should be greater at this stage than at the younger stages. Hence, a Kruskal-Wallis test was used to test the significance of the difference found between weight data for NVI in the 5 experiments.

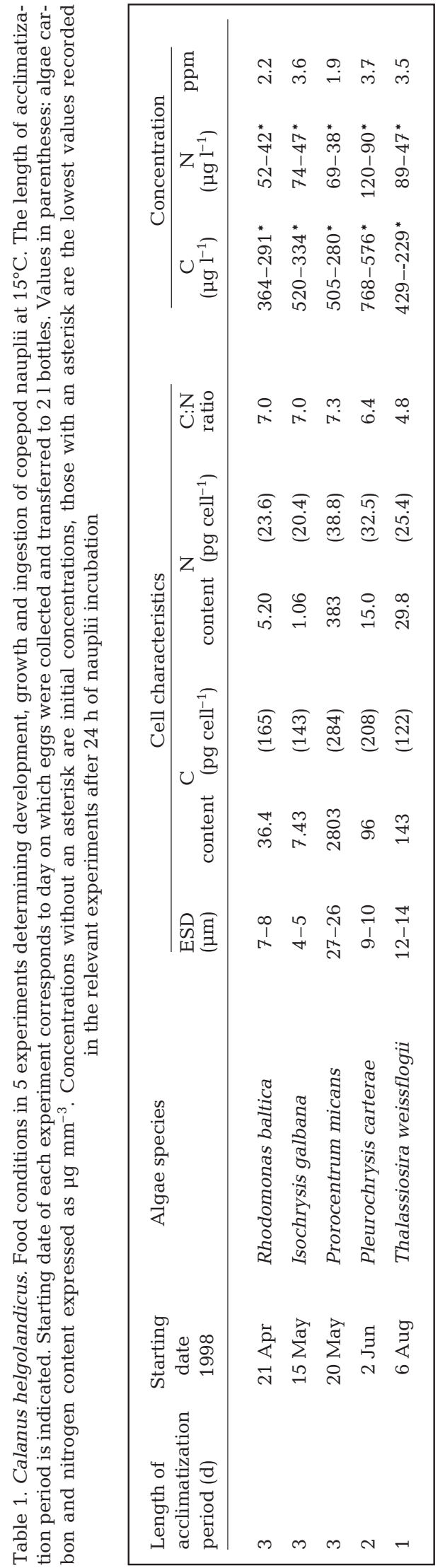


Growth rate. The naupliar growth rate was calculated for each experimental diet by fitting a linear model relating $\ln$ (mean weight) $\left(\hat{W}_{t}\right)$ to time (a method similar to that used by Koski et al. 1998). From Day 2 (characterised by NII) to Day 9 (last day) of each experiment, $\hat{W}_{t}$ was calculated daily as follows:

$$
\hat{W}_{t}=\sum_{i=1}^{6} f_{t i} \times w_{i}
$$

where i represents the stage number ranging from NII to $\mathrm{CI}, f_{t i}$ is the frequency distribution of Stage $i$ at Day $t$, and $w_{i}$ is the weight of Stage i. This growth model does not consider the value of $\hat{W}_{t}$ at Days 0 and 1 since weight decreases from egg to NII stage due to respiratory losses and sheding of the exoskeleton. Between Days 2 and 3, weight also decreases slightly from Stage NII to the newly moulted NIII stage, but this can be ignored. The weight of NII was not measured in 2 experiments (Rhodomonas baltica and Isochrysis galbana): thus, for all experiments, we used the mean weight of Stage NII calculated from the data from the 3 other experiments (see Table 4). In the case of I. galbana, no weight measurements were available for NIII, and we used the mean calculated from the data from the other 4 experiments. This means that we disregarded the slight effect of the algal diet on the weight of the Naplii NIII in this experiment.

We used analysis of covariance (ANCOVA) to compare the slopes and the intercepts of the 5 regression lines for each algal treatment $(T)$ where time was the covariate $(X)$ and mean weight $\hat{W}_{t}$ was the variate $(Y)$. Subsequently, an analysis of variance (ANOVA) was performed to test whether the slope of each of the regression lines was significantly different from zero, indicating whether mean weight increased over time.

Ingestion rates and gross growth efficiency. Ingestion rate was measured for each naupliar feeding stage in all experiments for individuals collected on the first day of each stage. Groups of 15 nauplii were placed in $200 \mathrm{ml}$ glass bottles filled with filtered sea water and provided with the same algal concentration as in the 21 bottles. Four replicates, and 4 controls, were placed on the rotating wheel for a $24 \mathrm{~h}$ incubation. Cell concentrations at the beginning and at the end of the experiments were measured using the Coulter Multisizer. For Stages NIV to NVI, some of the nauplii $(<30 \%)$ moulted to the next stage during the $24 \mathrm{~h}$ incubation. We did not consider this stage-shift in the calculation of ingestion rates, since ingestion is certainly not constant within a stage: the copepods may stop feeding during the moulting process and then increase their feeding activity after molting has been completed. However, as this stage-shift was similar for all algal diets, we were able to compare ingestion between experiments. Filtration and ingestion rates were calcu- lated following Frost (1972). The same statistical analysis as that for the linear models of growth was used to compare the linear models relating filtration or ingestion rate to development stage.

The specific ingestion rate $\left(I S_{i}\right)$ of the Stage $i$ was determined as the ratio of the ingestion of the Stage $i$ divided by its weight $\left(w_{i}\right)$. An average specific ingestion rate was calculated in each experiment by:

$$
I s=\sum_{i=\mathrm{NIII}}^{\mathrm{NV}} \frac{\Delta T_{i}}{\sum_{i=\mathrm{NIII}}^{\mathrm{NV}} \Delta T_{i}} \times I S_{i}
$$

where $\Delta T_{i}$ represents the duration of Stage $i$. The calculation of Is did not take into account Stage NVI because the duration of NVI was not available for some experiments. Finally, gross growth efficiency was calculated for each experiment as the ratio of the mean growth rate of nauplii versus the mean specific ingestion rate.

Field samples. Four vertical net hauls (100 $\mu \mathrm{m}$ mesh) were collected on each sampling day between April and August 1998 at Stn L4. Two of the samples were brought back to the laboratory and placed in the cold room at $15^{\circ} \mathrm{C}$ for the isolation of living nauplii NV, NVI and CI for CHN samples. The other 2 samples were preserved for subsequent length measurements.

Water samples for microplankton species identification were also collected on these sampling days and preserved with $2 \%$ Lugol's iodine solution. Cell volume and carbon estimates for the microplankton were obtained as described by Pond et al. (1996).

Rhodomonas baltica. The experiment with $R$. baltica was not set up in exactly the same way as the other experiments. Four 21 bottles plus 1 control were used for the experiment, and the eggs initially incubated had been spawned within a $24 \mathrm{~h}$ period (they were spawned within a $12 \mathrm{~h}$ period in the other experiments). Thus, the results for $R$. baltica are less conclusive. We intended to repeat the same experiment in duplicate, using eggs laid within a $12 \mathrm{~h}$ period because of these differences. However, on both occasions, $R$. baltica tended to clump, leading to entanglement and death of young nauplii. Similar results have been reported previously by Corkett et al. (1986) for a Rhodomonas species.

\section{RESULTS}

\section{Cohort development and mortality rates of Calanus helgolandicus}

The cumulative frequencies of numbers of individuals per stage (Fig. 1) reflect the development of the respective cohorts. Table 2 presents the estimates of the stage duration derived from Fig. 1 (see 'Methods'). 

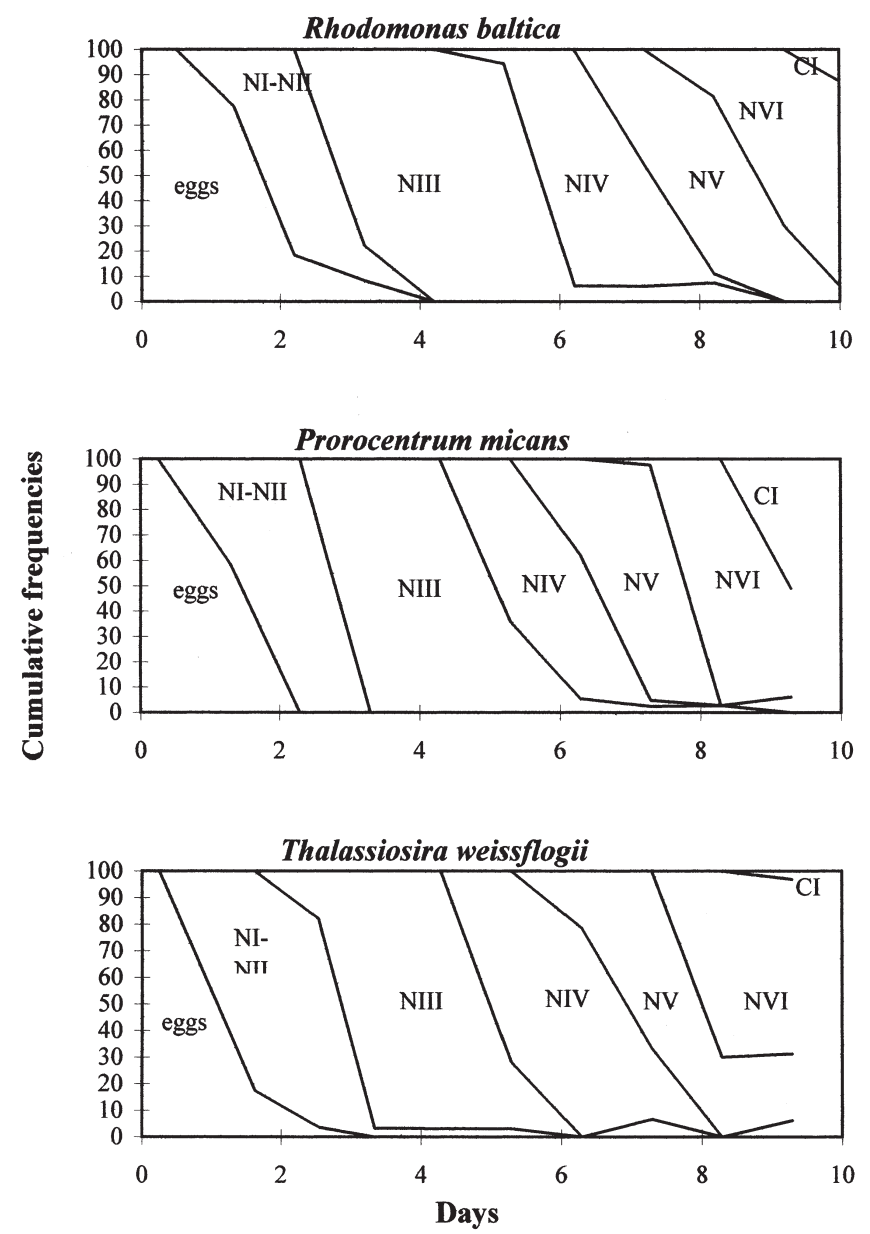

Naupliar development was not isochronal, since in all experiments the duration of the naupliar Stage NIII was longest. The duration of the other naupliar stages was similar, except for Stages NI and NII whose combined duration was more similar to the hatching time required by the eggs. Comparison of total developmental duration from egg to the end of Stage NV obtained with the various algal diets shows that development was faster for cohorts reared on Isochrysis galbana and Prorocentrum micans. However, the data for P. micans in Fig. 1 show the presence of late-develop-
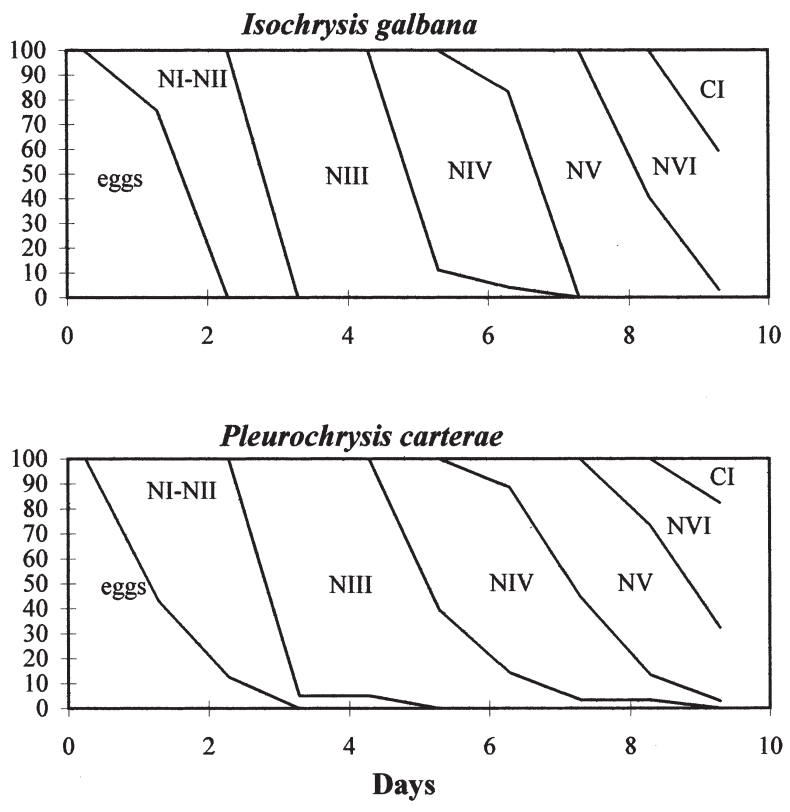

Fig. 1. Calanus helgolandicus. Cumulative frequencies of individual numbers per development stage, from egg to Copepodite Stage C1, in the 5 experiments. Each cohort originated from eggs spawned within a $12 \mathrm{~h}$ period, except for those in the $R$. baltica experiment (see 'Methods')

ing individuals in Stages NIII to NV, suggesting a wider range of variability in development of copepods fed this alga than in copepods fed I. galbana. Latedeveloping individuals were also found in the experiments run with Pleurochrysis carterae and Thalassiosira weissflogii.

The mortality rate $(\mathrm{M})$ of each bottle was calculated when there was no more larvae inside bottles, by considering: $M=\left(\left(N_{\mathrm{o}}-N_{\mathrm{s}}\right) / N_{\mathrm{o}}\right)$, where $N_{\mathrm{s}}=$ the number of individuals which died due to sampling mortality and $N_{\mathrm{o}}=$ the initial number. Mortality rates varied a lot

Table 2. Calanus helgolandicus. Stage durations (d) from egg to Naupliar Stage NVI,estimated by method of 'median development time' (Peterson \& Painting 1990), obtained for cultures with the 5 algae species. In 3 cases, the duration of Stage NVI was not available (-) because the cumulative frequency of this stage was less than $50 \%$ at the end of the experiment

\begin{tabular}{|lccccccc|}
\hline Alga & Eggs & NI-NII & NIII & NIV & NV & NVI & Eggs-NV \\
\hline Rhodomonas baltica & 1.7 & 1.2 & 2.9 & 1.6 & 1.5 & - & 8.8 \\
Isochrysis galbana & 1.5 & 1.3 & 2.1 & 1.8 & 1.4 & 1.4 & 8.1 \\
Prorocentrum micans & 1.3 & 1.5 & 2.3 & 1.4 & 1.3 & 1.5 & 7.8 \\
Pleurochrysis carterae & 1.3 & 1.5 & 2.3 & 2.1 & 1.7 & - & 8.8 \\
Thalassiosira weissflogii & 1.2 & 1.6 & 2.1 & 1.9 & 1.5 & - & 8.4 \\
\hline
\end{tabular}


among the set of bottles of an experiment, and, on average, were quite high ( $45 \%)$. This result was surprising, since the copepods used for different analyses were all in good condition (see 'Discussion').

\section{Body size and weight}

Body-size data are presented in Table 3. For the first 3 (non-feeding) stages (egg to NII), we found significant differences between the mean values obtained in the 5 experiments (especially for the egg stage). However, no trend could be detected throughout these 3 successive stages. For the feeding stages (NIII to CI), some trends were apparant; e.g. in all these stages, cephalothorax length of nauplii measured in the Rhodomonas baltica experiment was consistantly among the longest measured in all experiments. Also, the length of NV to CI fed on Prorocentrum micans was significantly small compared to individuals fed on the other diets.

The carbon (C) and nitrogen (N) contents of the nonfeeding stages (Fig. 2) decreased from egg to NII in the 3 experiments for which data were available. Subsequently, a weight increase was observed between each succesive stage and also between successive days within any one stage (Fig. 2). The highest $\mathrm{C}$ and $\mathrm{N}$ contents for late NV to NVI were observed in the Rhodomonas baltica and Isochrysis galbana experiments; in the case of the latter species, this was also true for Stage CI. The lowest C contents for NVI to CI were found in the Prorocentrum micans experiment. The N content for late NV to CI in the Thalassiosira weissflogii experiment showed a wide range of variability. The average $\mathrm{C}$ and $\mathrm{N}$ contents for each stage as well as the C:N ratios are presented in Table 4. Comparison of the weight of NVI in the 5 experiments shows that the body carbon levels with the $P$. micans diet was significantly lower than that with the $R$. baltica and I. galbana diets at the $5 \%$ level. No significant difference was found in the body nitrogen content. The C:N ratio was above 5 for all stages in the experiments with $R$. baltica and T. weissflogii, whereas in the other 3 experiments the $\mathrm{C}: \mathrm{N}$ ratio was below 5 .

\section{Field samples}

Environmental data from the English Channel off Plymouth are shown in Fig. 3. From late April to late August the temperature increased from 10 to $15^{\circ} \mathrm{C}$, and the total estimated carbon concentration of the microplankton community varied between 31 and $129 \mu \mathrm{g} \mathrm{l}^{-1}$ during the sampling period. The cephalothorax length and the $\mathrm{C}$ and $\mathrm{N}$ content of Stages NV to CI collected from the field (Table 5) appeared to be negatively related to temperature. However, food level may also have played an important role, since the size and weight of the nauplii fell on 27 May and 2 June after the carbon concentration of the microplankton had been low for about $10 \mathrm{~d}$ previously.

\section{Length-weight relation and growth rates}

The length-weight relation and the mean growth rate of the naupliar feeding stages fed on the 5 algae are presented in Table 6. Growth was exponential. The highest average growth rates in terms of carbon were

Table 3. Calanus helgolandicus. Egg diameter, caphalothorax (ct) and cephalosome (c) length ( $\mu$ m) of nauplii and Copepodite Stage CI from the 5 experiments. Data are means \pm SD with mean usually calculated from 30 values (see 'Methods'). Multiple comparison tests which cephalothorax length among those found in the different experiments are significantly different, for each successive stage, whereby each experiment is indicated by the first 2 letters of an algal species (e.g. $R b$ for $R$. baltica). Experiments in which lengths were significantly similar are separated by a comma, those in which lengths differed are separated by $<$ or $\leq$

\begin{tabular}{|c|c|c|c|c|c|c|c|c|c|}
\hline Alga & & Eggs & NI & NII & NIII & NIV & NV & NVI & CI \\
\hline \multirow[t]{2}{*}{ Rhodomonas baltica } & ct & $182 \pm 8$ & $217 \pm 8$ & $238 \pm 10$ & $408 \pm 15$ & $515 \pm 26$ & $621 \pm 24$ & $767 \pm 52$ & $763 \pm 26$ \\
\hline & $\mathrm{C}$ & & & $272 \pm 12$ & $333 \pm 12$ & $384 \pm 14$ & $439 \pm 7$ & & \\
\hline \multirow[t]{2}{*}{ Isochrysis galbana } & ct & $178 \pm 6$ & $217 \pm 5$ & $235 \pm 12$ & $386 \pm 15$ & $485 \pm 14$ & $572 \pm 15$ & $709 \pm 25$ & $756 \pm 13$ \\
\hline & $\mathrm{C}$ & & & $268 \pm 10$ & $326 \pm 9$ & $368 \pm 7$ & $411 \pm 8$ & & \\
\hline \multirow[t]{2}{*}{ Prorocentrum micans } & ct & $175 \pm 5$ & $216 \pm 11$ & $255 \pm 7$ & $391 \pm 15$ & $499 \pm 12$ & $570 \pm 17$ & $645 \pm 32$ & $687 \pm 29$ \\
\hline & $\mathrm{C}$ & & & $265 \pm 12$ & $340 \pm 8$ & $372 \pm 9$ & $387 \pm 16$ & & \\
\hline \multirow[t]{2}{*}{ Pleurochrysis carterae } & ct & $173 \pm 4$ & $208 \pm 16$ & $240 \pm 10$ & $385 \pm 17$ & $471 \pm 26$ & $570 \pm 29$ & $679 \pm 48$ & $732 \pm 27$ \\
\hline & $\mathrm{C}$ & & & $260 \pm 13$ & $324 \pm 15$ & $363 \pm 10$ & $397 \pm 16$ & & \\
\hline \multirow[t]{2}{*}{ Thalassiosira weissflogii } & ct & $188 \pm 5$ & $216 \pm 11$ & $246 \pm 12$ & $397 \pm 17$ & $475 \pm 33$ & $585 \pm 48$ & $681 \pm 58$ & $694 \pm 18$ \\
\hline & $\mathrm{C}$ & & & $267 \pm 13$ & $325 \pm 20$ & $377 \pm 13$ & $407 \pm 15$ & & \\
\hline $\begin{array}{l}\text { Multiple comparison } \\
\text { tests }\end{array}$ & & $\begin{array}{l}P C \leq I g \\
P m I g \\
P m \leq R b \\
R b \leq T W\end{array}$ & $\begin{array}{l}P C_{1} P P_{1} I g \\
R b, T_{W}\end{array}$ & $\begin{array}{r}R b, I g, P C_{1} \\
T w<P m\end{array}$ & $\begin{array}{c}I g_{1} P_{C} \leq P m \\
T w, P m \\
T w \leq R b\end{array}$ & $\begin{aligned} P C & \leq T w \\
T w & \leq I g \\
I g & \leq P m \\
P m & \leq R b\end{aligned}$ & $\begin{array}{l}I g, P m_{1} \\
P_{C} \leq T W \\
T W \leq R b\end{array}$ & $\begin{array}{c}P m \leq P_{C} \\
T W_{1} P_{C} \\
T w \leq I g \\
I g \leq R b\end{array}$ & $\begin{array}{r}P m<R b, \\
I g, P C, T W\end{array}$ \\
\hline
\end{tabular}



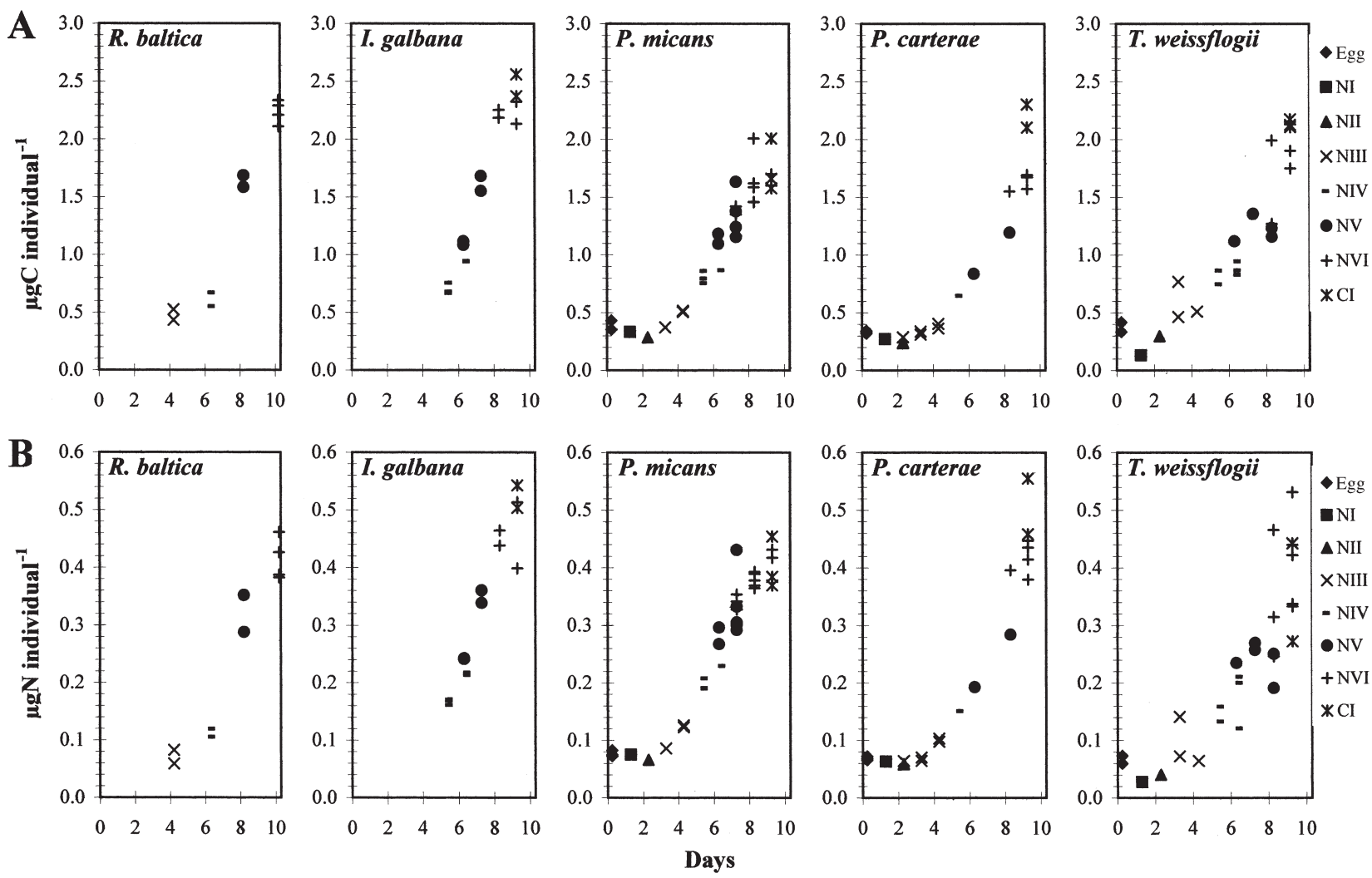

Fig. 2. Calanus helgolandicus. Body carbon (A) and nitrogen (B) of stages from egg to Copepodite Stage CI raised in 5 experiments with different algal diets (full specific names in Fig. 1). Day zero is day upon which $50 \%$ of the eggs were spawned

observed on the Isochrysis galbana diet and the lowest values with the Pleurochrysis carterae diet; however, ANCOVA revealed these differences to be non-significant. The mean growth rate expressed in term of nitrogen was also highest with Rhodomonas baltica and I. galbana diets. The $\mathrm{C}$ growth rates were slightly lower than the $\mathrm{N}$ growth rates on all algal diets except R. baltica.

\section{Ingestion rates}

Filtration and ingestion rates in terms of carbon and volume of each naupliar stage fed on the different algal diets are presented in Tables 7 \& 8, respectively. An ANCOVA performed on the filtration or the ingestion rates showed that the slopes of the 5 regression lines which describe filtration or ingestion rates versus naupliar stages were not significantly different ( $p>0.05)$, whereas the intercepts of the 5 regression lines were significantly different $(\mathrm{p}<0.05)$, indicating that the filtration (or ingestion) rate varied as a function of algal diet. The highest filtration and ingestion rates were observed with the largest cells, Prorocentrum micans,
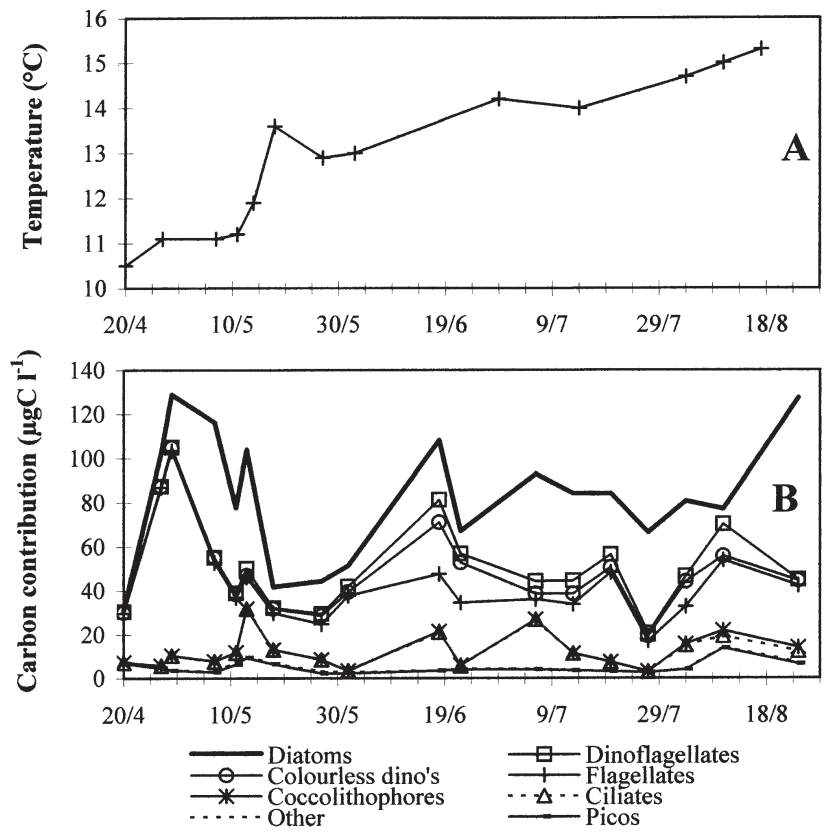

Fig. 3. Environmental data measured in the English Channel off Plymouth in 1998 (day/month given on abscissas). (A) Mean water-column temperature, (B) carbon contribution of microplankton species 

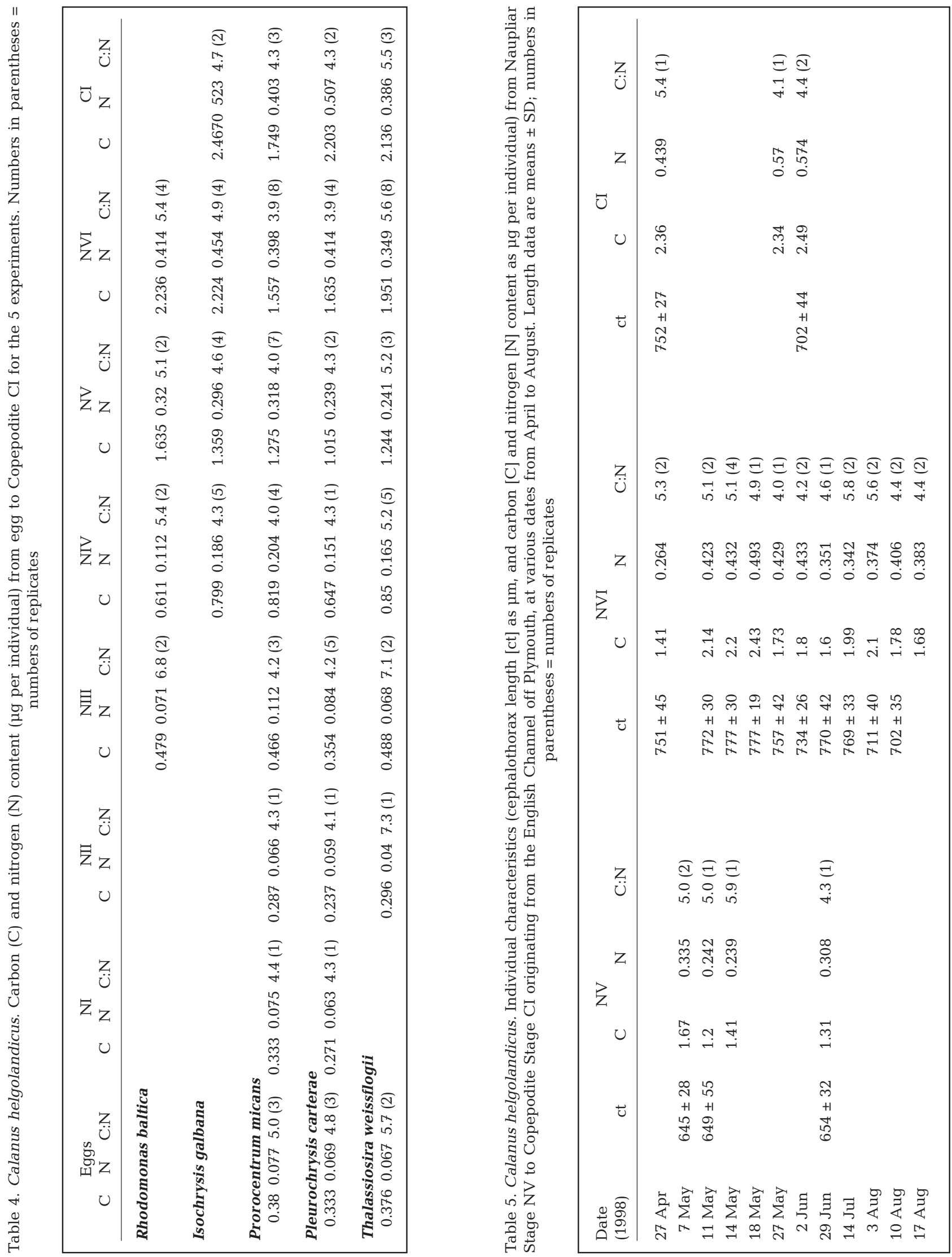
Table 6. Calanus helgolandicus. Relationship between cephalothorax length $(\mathrm{L}, \mu \mathrm{m})$ and weight $(\mathrm{W})$ and carbon and nitrogen content $\left(\sim \mu \mathrm{g}\right.$ ind.$\left.^{-1}\right)$ from Stages NIII to NVI. Parameters are of linear growth model relating ln(mean weight) to time (see 'Methods'). In all regressons, slopes were found significantly different from zero at the $5 \%$ level. ANCOVA to compare growth models for different algal diets shows that they are not significantly different at the $5 \%$ level in terms of either $\mathrm{C}$ or $\mathrm{N}$ )

\begin{tabular}{|c|c|c|c|c|c|c|}
\hline \multirow[t]{2}{*}{ Alga } & & \multirow[t]{2}{*}{ Length-weight relationship } & \multicolumn{4}{|c|}{ Growth model } \\
\hline & & & Slope & Intercept & (n) & $\mathrm{R} 2$ \\
\hline Rhodomonas baltica & $\begin{array}{l}\mathrm{C} \\
\mathrm{N}\end{array}$ & $\begin{array}{l}\mathrm{W}=2.150 \mathrm{E}-08 \times \mathrm{L} 2.794 \\
\mathrm{~W}=3.315 \mathrm{E}-10 \times \mathrm{L} 3.180\end{array}$ & $\begin{array}{l}0.2777 \\
0.2962\end{array}$ & $\begin{array}{l}-1.9382 \\
-3.7904\end{array}$ & $\begin{array}{l}(8) \\
(8)\end{array}$ & $\begin{array}{l}0.94 \\
0.91\end{array}$ \\
\hline Isochrysis galbana & $\begin{array}{l}\mathrm{C} \\
\mathrm{N}\end{array}$ & $\begin{array}{l}\mathrm{W}^{\mathrm{a}}=5.214 \mathrm{E}-08 \times \mathrm{L} 2.681 \\
\mathrm{~W}^{\mathrm{a}}=5.575 \mathrm{E}-09 \times \mathrm{L} 2.788\end{array}$ & $\begin{array}{l}0.3040^{\mathrm{a}} \\
0.3183^{\mathrm{a}}\end{array}$ & $\begin{array}{l}-1.9539^{\mathrm{a}} \\
-3.6072^{\mathrm{a}}\end{array}$ & $\begin{array}{l}(8) \\
(8)\end{array}$ & $\begin{array}{l}0.98 \\
0.97\end{array}$ \\
\hline Prorocentrum micans & $\begin{array}{l}\mathrm{C} \\
\mathrm{N}\end{array}$ & $\begin{array}{l}\mathrm{W}=1.680 \mathrm{E}-08 \times \mathrm{L} 2.485 \\
\mathrm{~W}=2.035 \mathrm{E}-08 \times \mathrm{L} 2.600\end{array}$ & $\begin{array}{l}0.2591 \\
0.2795\end{array}$ & $\begin{array}{l}-1.7600 \\
-3.3048\end{array}$ & $\begin{array}{l}(8) \\
(8)\end{array}$ & $\begin{array}{l}0.97 \\
0.95\end{array}$ \\
\hline Pleurochrysis carterae & $\begin{array}{l}\mathrm{C} \\
\mathrm{N}\end{array}$ & $\begin{array}{l}\mathrm{W}=4.673 \mathrm{E}-08 \times \mathrm{L} 2.66 \\
\mathrm{~W}=5.846 \mathrm{E}-09 \times \mathrm{L} 2.769\end{array}$ & $\begin{array}{l}0.2431 \\
0.2605\end{array}$ & $\begin{array}{l}-1.9461 \\
-3.5063\end{array}$ & $\begin{array}{l}(8) \\
(8)\end{array}$ & $\begin{array}{l}0.96 \\
0.97\end{array}$ \\
\hline Thalassiosira weissflogii & $\begin{array}{l}\mathrm{C} \\
\mathrm{N}\end{array}$ & $\begin{array}{l}\mathrm{W}=1.857 \mathrm{E}-07 \times \mathrm{L} 2.475 \\
\mathrm{~W}=2.152 \mathrm{E}-09 \times \mathrm{L} 2.909\end{array}$ & $\begin{array}{l}0.2654 \\
0.2853\end{array}$ & $\begin{array}{l}-1.7922 \\
-3.648\end{array}$ & $\begin{array}{l}(8) \\
(8)\end{array}$ & $\begin{array}{l}0.96 \\
0.95\end{array}$ \\
\hline
\end{tabular}

Table 7. Calanus helgolandicus. Filtration rates from Naupliar Stages NIII to NVI (ml nauplius $\left.{ }^{-1} \mathrm{~d}^{-1}\right)$ recorded for nauplii fed different algae. ANOVA compares filtration rates between stages and shows that rates are not significantly different at $5 \%$ level. Data are means \pm SD (number of replicates)

\begin{tabular}{|c|c|c|c|c|}
\hline Alga & NIII & NIV & NV & NVI \\
\hline Rhodomonas baltica & $0.92 \pm 0.08$ & $1.353 \pm 0.210$ & $2.592 \pm 0.596$ & $1,577 \pm 0.117$ \\
\hline Isochrysis galbana & $0.602 \pm 0.301$ & $0.544 \pm 0.018$ & $0.427 \pm 0.150$ & $0.775 \pm 0.348$ \\
\hline Prorocentrum micans & $3.252 \pm 1,202$ & $2.925 \pm 0.515$ & $3.008 \pm 0.485$ & $3.935 \pm 0.688$ \\
\hline Pleurochrysis carterae & $1.18 \pm 0.290$ & $1.259 \pm 0.572$ & $1.745 \pm 0.101$ & $1.357 \pm 0.205$ \\
\hline Thalassiosira weissflogii & $0.863 \pm 0.279$ & $1.666 \pm 0.493$ & $2.357 \pm 0.670$ & $1.957 \pm 0.453$ \\
\hline
\end{tabular}

Table 8. Calanus helgolandicus. Daily rates of ingestion of algae, calculated separately for each naupliar stage from NIII to NVI expressed as (Vol) $10^{-4} \mathrm{~mm}^{3}$ nauplius ${ }^{-1} \mathrm{~d}^{-1}$ and also as (C) $\mu \mathrm{gC}$ nauplius ${ }^{-1} \mathrm{~d}^{-1}$ recorded for nauplii fed different algae. ANOVA compares ingestion rates between stages and shows that rates are not significantly different at $5 \%$ level. Data are means $\pm \mathrm{SD}$

\begin{tabular}{|llcccc|}
\hline Alga & & NIII & NIV & NV & NVI \\
\hline Rhodomonas baltica & Vol & $19.5 \pm 1.8$ & $28.1 \pm 4.4$ & $51.7 \pm 10.6$ & $32,60 \pm 3.4$ \\
& C & $0.323 \pm 0.029$ & $0.464 \pm 0.072$ & $0.855 \pm 0.175$ & $0,539 \pm 0.056$ \\
Isochrysis galbana & Vol & $23.4 \pm 11.4$ & $28.4 \pm 0.80$ & $21.7 \pm 5.4$ & $33.1 \pm 12.6$ \\
& C & $0.328 \pm 0.16$ & $0.398 \pm 0.011$ & $0.305 \pm 0.038$ & $0.465 \pm 0.176$ \\
Prorocentrum micans & Vol & $48.7 \pm 17.7$ & $49.2 \pm 7.7$ & $49.5 \pm 7.09$ & $65.6 \pm 10.8$ \\
& C & $1.384 \pm 0.503$ & $1.396 \pm 0.218$ & $1.405 \pm 0.201$ & $1.861 \pm 0.306$ \\
Pleurochrysis carterae & Vol & $49.2 \pm 9.3$ & $42.7 \pm 19.0$ & $48.2 \pm 2.2$ & $37.7 \pm 5.2$ \\
Thalassiosira weissflogii & Vol & $1.024 \pm 0.194$ & $0.89 \pm 0.396$ & $1.003 \pm 0.045$ & $0.786 \pm 0.108$ \\
& C & $37.3 \pm 11.6$ & $63.3 \pm 17.3$ & $85.4 \pm 21.7$ & $72.0 \pm 15.4$ \\
& & $0.454 \pm 0.141$ & $0.771 \pm 0.211$ & $1.04 \pm 0.264$ & $0.877 \pm 0.188$ \\
\hline
\end{tabular}

and the lowest rates were found with the smallest algae Rhodomonas baltica and Isochrysis galbana. When the ingestion rates are expressed in terms of nitrogen, those achieved with the Thalassiosira weissflogii are rather high compared to those achieved with other algae because of the low $\mathrm{C}: \mathrm{N}$ ratio of $T$. weissflogii (Table 1). Subsequent ANOVAs successively performed for each algal treatment on the filtration (or ingestion) rates showed that there was no significant difference between these rates estimated for the different naupliar stages. When the experimental data were pooled, the specific ingestion rate was negatively related to the body weight of the successive naupliar stages (Fig. $4 ; \mathrm{p}<0.05$ ). 


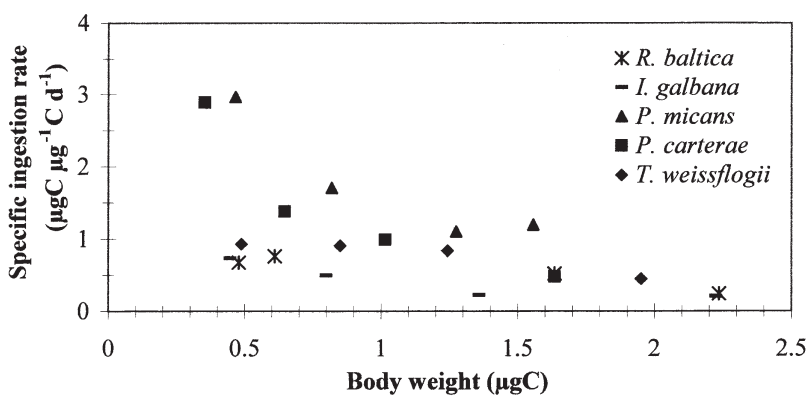

Fig. 4. Calanus helgolandicus. Specific ingestion rate (carbon ingested $\mathrm{d}^{-1} \mu \mathrm{g} \mathrm{C}^{-1}$ body weight) as a function of the body weight of each naupliar stage. (Full specific names of algal diet are given in Fig. 1)

\section{Growth efficiency}

Average gross growth efficiencies (GGE), expressed in terms of carbon (GGEC) and nitrogen (GGEN) calculated from Stages NIII to NVI are presented in Fig. 5. GGEN is higher than GGEC for each experiment, except in the case of the Thalassiosira weissflogii diet. However, when the results of the different algal diets are compared, we observe the same trend in both GGEC and GGEN. GGE is an index describing the ratio of the growth rates divided by the specific ingestion rates (see 'Methods'). The highest GGE (0.59 for $\mathrm{C}$ and 0.88 for N) was observed for the diet with the smallest alga, Isochrysis galbana, which resulted in the highest growth (Table 6) but the lowest ingestion rates (Fig. 4). With the Rhodomonas baltica diet, the growth rates were high and ingestion was low, which explains the rather high value of GGE ( 0.42 for $\mathrm{C}$ and 0.52 for $\mathrm{N}$ ) with this diet. The lowest GGEs were found with the Prorocentrum micans and Pleurochrysis carterae (0.12 for $\mathrm{C}, 0.23$ for $\mathrm{N}$; 0.13 for $\mathrm{C}, 0.21$ for $\mathrm{N}$, respectively) diets, with which growth was rather low and ingestion the highest recorded. Finally, nauplii fed on T. weissflogii had an intermediate value of GGE (0.29 for $\mathrm{C}$ and 0.26 for $\mathrm{N})$.

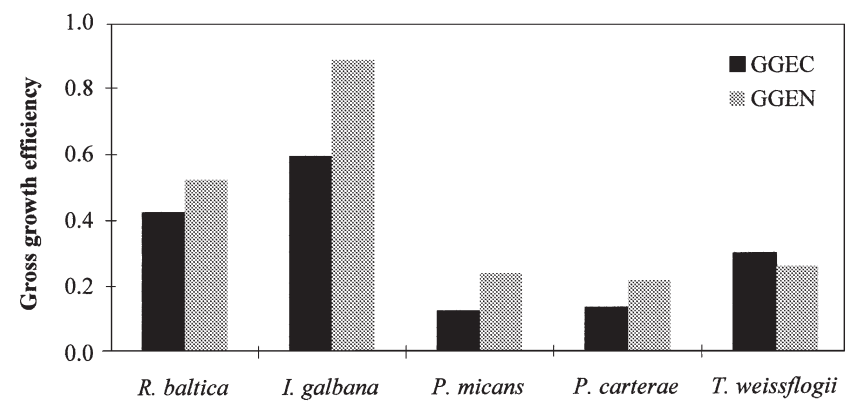

Fig. 5. Calanus helgolandicus. Gross growth efficiency in terms of carbon (GGEC) and nitrogen (GGEN) of nauplii feeding on 5 algal species (full specific names in Fig. 1)

\section{DISCUSSION}

To date, few data are available in the literature on the bioenergetic processes of naupliar stages of copepods. In the case of Calanus helgolandicus, naupliar studies have only been reported by Thompson (1982; but some specimens of $C$. finmarchicus were also present among his samples), Diel \& Klein Breteler (1986) and Green et al. (1991, 1992). The C. helgolandicus used in experiments by Mullin \& Brooks (1970) and Paffenhöfer $(1971,1976)$ has since been identified as C. pacificus (Fernández 1979b). The present study presents data for a series of key parameters in the population dynamics of $C$. helgolandicus nauplii.

\section{Initial conditions}

Before discussing our results, it is important to consider whether the initial characteristics of the egg (biochemical composition and size) can influence subsequent growth. The eggs used in our experiments were spawned by females that had been fed for at least $1 \mathrm{~d}$ with excess food in order to standardise egg characteristics (see 'Methods'). Guisande \& Harris (1995) found positive relationships between food availability during spawning and egg volume and their hatching success, but this was not confirmed by Pond et al. (1996). Laabir et al. (1999) emphasised the role of essential amino acids in the food available during spawning in hatching success, which tends to support the results of Guisande \& Harris (1995). In this latter study, the authors showed that after $3 \mathrm{~d}$ of female incubation with excess food, egg size reached a maximum threshold very close to that recorded in our experiments run with the same acclimatization period (Table 1). Compared to the wide range of values reported in the literature, the variations in egg size and weight between our experiments were quite low (Pond et al. 1996).

Guisande \& Harris (1995) found a strong positive relationship between egg size and naupliar length at death after starvation (i.e. certainly Nauplii NIII); this suggests that nauplii from the smallest eggs remain the smallest at least until they start eating. In our study, we found also that the eggs, NI and NII of copepods fed Pleurochrysis carterae were the smallest and lightest of all experiments. This was not the case anymore during the subsequent stages, suggesting that factors other than the initial characteristics (e.g. the algal diet) influence naupliar growth. Melle (1998) also showed that maternal characteristics have a minor effect on offspring growth patterns from Stage NIII onwards. Females isolated from the wild samples in our study were also measured at different times of year (C.R. 
unpubl. data), and there was apparently no relationship between size of the females and size of the eggs produced after an incubation period of 1 to $3 \mathrm{~d}$. All these considerations tend to support the idea that the differences in egg characteristics at the start of each experiment were small, and do not affect our conclusion concerning the effect of algal diet on growth patterns.

\section{Filtration and ingestion rates}

The major factor known to influence filtration and ingestion rates is food concentration (Frost 1972). Another factor, food characteristics, especially algal size, affects feeding processes (Paffenhöfer 1971, 1976, Fernández 1979b, Støttrup \& Jensen 1990). A positive relationship between algal size and filtration rates has often been reported for adult copepods (Frost 1972).

Insufficient size prevents some algae from being retained by the naupliar mouthparts. Fernández (1979b) found for example that Calanus pacificus nauplii were not able to fed on Isochrysis galbana because of their small size. However, this was not the case in our experiments with $C$. helgolandicus nauplii (see also Green et al. 1991), which suggests that there may be size-retention differences between the mouthparts of the nauplii of these 2 Calanus species.

Ingestion rates expressed in terms of both $\mathrm{mm}^{3}$ and $\mu \mathrm{gC}$ per nauplius per day are shown in Table 8, which reveals that the highest ingestion rate varies as a function of unit used. When ingestion is expressed as $\mathrm{mm}^{3}$ of algae, then nauplii fed on Thalassiosira weissflogii exhibited a higher ingestion rate than those fed on Prorocentrum micans. When ingestion is expressed as $\mu \mathrm{gC}$, the opposite is true because of the higher carbon content of $P$. micans. Apart from this, both ingestion units show almost the same trend. The ingestion rate recorded for each algal diet is related to algal size (Fig. 6A). In other words, even more cells are ingested in the case of small algae, the carbon-converted ingestion rate is higher for large algae than for small algae. The naupliar ingestion rates measured in our experiments are similar to those reported by Fernández (1979b: 0.3 to $1.9 \mu \mathrm{gC}$ nauplius ${ }^{-1} \mathrm{~d}^{-1}$ ).

Ingestion rate is also known to depend on copepod stage (Mullin \& Brooks 1970, Paffenhöfer 1971, Allan et al. 1977). In our study, no significant increase in ingestion rate was apparent through the successive stages (Table 8). In contrast, we found that daily ration decreased with increasing naupliar stages; a similar relationship was reported by Paffenhöfer $(1971,1976)$, but not by Fernández (1979b). Our results could have been biased since some individuals moulted during the ingestion experiments at Stages NIV, NV and NVI (see 'Methods'); this may have contributed to masking an increase in ingestion rates during these stages. However, it seems reasonable that higher daily rations are ingested by NIII, since this naupliar stage has been found to be the most sensitive to absence of food (Lopez 1991, 1996) and its energetic requirements are considered to be highest (Peterson 1986, Lopez 1996).

\section{Mortality rates}

The mortality rates we found in our experiments were quite high compared to those found in the literature for other Calanus species (Paffenhöfer 1970, Hirche 1980, Peterson 1986). It is difficult to explain such high mortality values since the copepods we used were all in good condition. Individuals that are moribund are easily detected by microscope observations (slow and abnormal swimming, abnormal shape of the nauplii). Our copepods were active, and were certainly not dying.
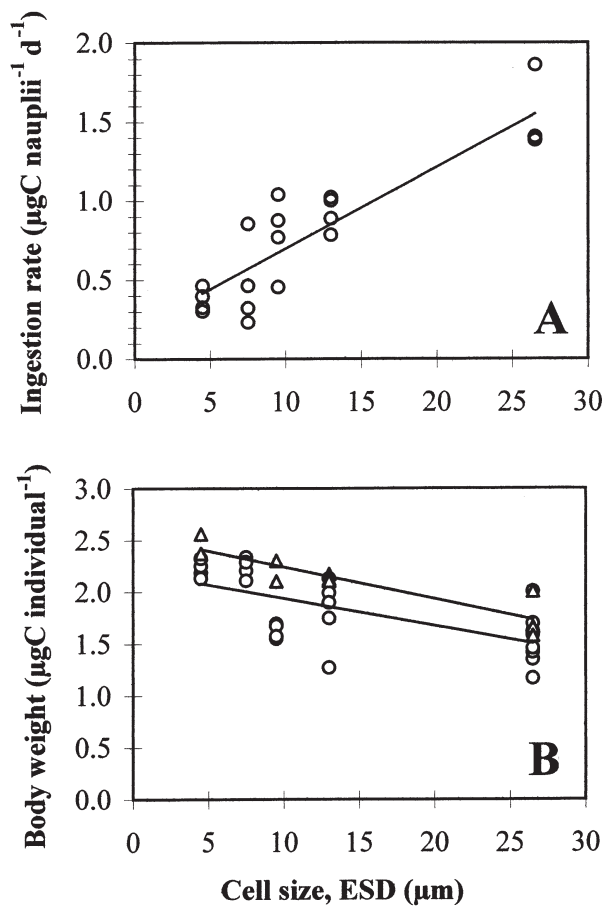

Fig. 6. Calanus helgolandicus. (A) Ingestion rate and (B) body weight in relation to cell size of algae, given as equivalent spherical diameter (ESD). Ingestion rates (A) for each algal size are 4 mean ingestion rates found for each stage (NIII to NVI) and given in Table 8; linear regression is ingestion = $0.0516 \mathrm{ESD}+0.184\left(\mathrm{R}^{2}=0.807\right)$. Body weights are replicates for Stage NVI $(O)$ and Stage CI $(\Delta)$; linear regressions are body weight of NVI $=-0.026 \mathrm{ESD}+2.20\left(\mathrm{R}^{2}=0.455\right)$ and body weight of $\mathrm{CI}=-0.081 \mathrm{ESD}+2.55\left(\mathrm{R}^{2}=0.806\right)$ 
One possible explanation of the high mortality is that some individuals were lost during the numerous manipulations of the bottles each day. Indeed, a significant proportion could easily have disappeared in this way, since individuals tended to stick to the surface and may have been lost with a few drops of water during opening and closing the bottles. However, the loss of such individuals can hardly explain the whole mortality recorded. Egg mortality, frequently reported as $\sim 20 \%$ in the literature (Guisande \& Harris 1995, Pond et al. 1996, Laabir et al. 1998), may have been even higher in our experiments because of manipulation of the eggs during isolation and transfer to the bottles. Also, the survival of the Naupliar Stages NI-NII, which are rather fragile (Lopez 1996), may have been affected by such manipulation.

A final possible explanation is that mortality was high in our experiments because of the laboratory culture conditions. In such a case, dead individuals would be the weakest individuals of a cohort and living individuals the healthiest. If such selective mortality did occur, this would mean that our calculation of growth rates was an overestimation because we did not consider those individuals which did not grow well. In other words, our mean growth rate did not take into consideration the growth of all individuals but only the apparent growth rate of the cohort. A similar distinction has been made previously when calculating development rates (Lopez 1991). It is difficult to conclude what exactly happened and each factor may have partly contributed to the high mortality we found. However, this would not affect our conclusion concerning the influence of the algal diets, since mortality was similar in all experiments.

\section{Specific growth rates}

The best known factors influencing specific growth rate are temperature and food concentration (Paffenhöfer 1976, Vidal 1980b, Thompson 1982, Peterson \& Painting 1990, Green et al. 1991). Food quality is another possible factor influencing the production rate of copepods, as reported by Klein Breteler et al. (1990) in studies on copepodite development and by Støttrup \& Jensen (1990), Jónasdóttir (1994) and Ianora et al. (1999) in studies on egg or spermatophore production rate, considered to be equivalent to copepodite growth rate for non-growing adults. In this paper, we found that those algae that produce the shortest duration of naupliar stages and those that produce the highest mean weight of Stages NV, NVI or CI (i.e. stages affected for the longest time by food quality) are not the same. Shortest development was achieved with Isochrysis galbana and Prorocentrum micans diets
(Table 2) whereas greatest weight or the body size of NV to CI were achieved with I. galbana and Rhodomonas baltica diets (Table $3 \& 4$ ). In other words, some algal diets play a major role in development time of copepods, whereas other algal diets influence weight.

Among the factors determining the quality of nontoxic algae, biochemical composition is particularly important (e.g. protein or lipid concentration) as is the 'digestibility' of the algae, which depends on, for example, the presence of an indigestible theca or frustule around the cells or the size of the algae (Hitchcock 1982, Støttrup \& Jensen 1990, Jónasdóttir 1994, Koski et al. 1998). Isochrysis galbana and Prorocentrum micans, the 2 algae which supported the fastest development, seem to be good diets for different reasons. Støttrup \& Jensen 1990 found that Acartia tonsa females fed on I. galbana utilised protein sources better than females fed on Rhodomonas baltica or Thalassiosira weissflogii, suggesting that $I$. galbana is an algae that is easily assimilated. P. micans is recognised as a good potential food because of its biochemical composition (Hitchcock 1982, Mayzaud et al. 1998). The nitrogen (hence protein) content shown in Table 1 is indeed highest for P. micans. Proteins are recognised as being of predominant importance in growth processes (Checkley 1980, Kiørboe et al. 1985). Low body $\mathrm{C}: \mathrm{N}$ ratios and hence high protein levels of $\mathrm{NV}$ to $\mathrm{CI}$ were measured in nauplii fed on $I$. galbana and $P$. micans. However, low body $\mathrm{C}: \mathrm{N}$ ratios were also found with a Pleurochrysis carterae diet-an alga that did not support fast development in our experiments.

As stated earlier, size is one of the important characteristics determining the suitability of the algae. In our study, we found a relationship between the mean carbon weight of Stages NVI and CI and algal diameter (Fig 6B), small algae providing a greater weight increment than larger algae. This was not observed by Paffenhöfer (1971), who reported that the Stages NV to CI of Calanus pacificus held at $15^{\circ} \mathrm{C}$ were slightly lower when fed the smallest alga (Lauderia borealis $19 \mu \mathrm{m}$ equivalent spherical diameter, ESD) than when fed the biggest algae (L. borealis, $36 \mu \mathrm{m} \mathrm{ESD;} \mathrm{or} \mathrm{Gymnodi-}$ nium spendens $60 \mu \mathrm{m}$ maximum width; see Paffenhöfer 1971, Table 2). However, the carbon concentration used in Paffenhöfer's experiments was much lower than in ours, since he used a concentration close to that found in the natural environment. Hence, in Paffenhöfers paper these concentrations were certainly limiting for growth and slight variation in the different algal concentrations may have affected growth and possibly masked the effect of different algal size on naupliar stages. As in our study, Støttrup \& Jensen (1990) found a negative relationship between algal size and specific egg production rate. Indeed, in their study, the specific egg production rate was higher with the smallest alga 
(Isochrysis galbana) and decreased with increasing algal size (large dinoflagellates), with the exception of Dunaliella tertiolecta, which produced a particularly low spawning response. In order to explain naupliar carbon weight as a response to algal diet, we must also consider the digestibility of the algae, since in our experiments the 3 largest algae were also those characterised by the presence of indigestible components around the cell (see below).

\section{Comparison with other body weight data}

The growth rates reported here (Table 6) compare well with previous results for Calanus species (reviewed by Green et al. 1991). Green et al. also reported population dynamic parameters measured on C. helgolandicus nauplii fed on different food concentrations of Isochrysis galbana, thus permitting direct comparison with our data obtained with the same alga. The growth rate reported by Green et al. (1991) $\left(\sim 0.25 \mathrm{~d}^{-1}\right)$ was lower than those found in our experiment. Our development times also seem to be somewhat longer - duration from NI to CI is $~ 8 \mathrm{~d}$. However, comparison is difficult, since Green et al. (1991) did not describe the methods used to estimate the stage durations. In regard to body size, the value they report for CI fed on high concentrations of I. galbana is close to our value (Table 3) and the range of variability for CI fed with the different algae diets in our experiments corresponds to the body size range found by Green et al. (1991) for concentrations of I. galbana ranging from $<100$ to $>900 \mu \mathrm{gC} \mathrm{l}^{-1}$.

The length data for the wild individuals in our study (Table 5) are higher than those in our experiments. This could be due to lower in situ temperatures than those we used in the laboratory (Deevey 1960, Vidal 1980b, Hopcroft \& Roff 1998, Melle 1998). Differences between food concentrations in the field and in the laboratory could also explain differences in growth patterns between wild and laboratory-reared nauplii. For example, the decrease in size observed in the field on 27 May and 2 June could have been due to a low microplankton carbon concentration during the preceding 10 d (Fig. 3; Lopez 1996).

Compared to experimental food concentrations, those from the field are rather low. However, it is difficult to say whether the nauplii collected in the field were always food-limited or not. Obviously, food is patchily distributed in the sea and this micro-scale heterogeneity tends to increase the variability between the growth patterns of wild individuals originating from the same cohort. Finally, weaker individuals may be lost from the field population because of higher mortality (Huntley \& Lopez 1992). Stage NIII has been recognised as the stage that is most sensitive to the absence of food (Lopez 1991, 1996). Individuals that we collected in the field (Stages NV to CI) may have been the strongest ones that had survived and grown well.

Comparison of the size of NVI collected when the temperature was $15^{\circ} \mathrm{C}$ (i.e. 10 August) with those in our experiments, reveals that the length of the wild NVI is close to those obtained with the small flagellate, Isochrysis galbana diet. Interestingly, small $5 \mu \mathrm{m}$ flagellates were also very abundant in the field on this date and during some days before. However, the weight of the wild NVI was lower than the laboratory individuals fed on $I$. galbana. This suggests that the critical weight that has to be reached in order to moult to the next stage (Carlotti et al. 1993) may be lower in the field, where the diet is more diverse than a single experimental algal diet. To better understand the influence of food quality on naupliar growth in the field, experiments with mixed diets are necessary; these would implicate examining the processes of feeding selectivity (Meyer-Harms et al. 1999, Irigoien et al. 2000a).

\section{Gross growth efficiency}

Gross growth efficiency (GGE) is a parameter resulting from a number of variables - growth rate, and specific ingestion rate. Consequently, GGE is also influenced by all the factors listed above (temperature, food concentration, food quality or copepod stage). The most commonly reported value of GGE ( 0.3) is attributed to both nauplii and copepodites and can be used to transform female egg production into ingestion rate (Kiørboe et al. 1985). However, our results (Fig. 5), indicate that there is a wide range of variability in GGE values, (from 0.12 to 0.59 for GGE in terms of carbon (GGEC)). The GGE values found with Rhodomonas baltica (0.42 for GGEC and 0.52 for GGEN) are close to those reported by Berggreen et al. (1988; 0.44 for GGEC) during growth of the copepod Acartia tonsa fed on the same alga. In general, the high values of GGE (>0.3) obtained with the 2 smallest algae (Isochrysis galbana and $R$. baltica) are distinct from the others $(<0.3)$. These results can be explained by differences in algal assimilation. The presence of an indigestible cellulose theca surrounding the Prorocentrum micans cell can explain the low assimilation rate of this algal diet, even though its biochemical components are considered to be of high quality (see above and Hitchcock 1982, Mayzaud et al. 1998). The same explanation applies to the sub-optimum GGE with Thalassiosira weissflogii and Pleurochrysis carterae, since their cells are surrounded by a silica frustule and a calcium layer, respectively. Size of the algae is also a factor which can 
determine their assimilation: the small size of $I$. galbana and $R$. baltica could have facilitated their assimilation by copepods.

\section{CONCLUSION}

These experiments on Calanus helgolandicus nauplii reared on 5 different algae at high carbon concentrations have enabled us to report data on ingestion, development, growth rates and gross growth efficiency. Development was faster with Prorocentrum micans and Isochrysis galbana diets, whereas the highest body carbon contents of the late naupliar stages NV and NVI and Copepodite CI were found with Rhodomonas baltica and I. galbana diets. These results suggest that, in algae, factors inducing faster development and those inducing higher weight within a stage are not the same. In other words, the potential critical weight of 1 stage necessary for moulting to the following stage is influenced not only by temperature (Carlotti et al. 1993) but also by food quality. We also found the gross growth efficiency of nauplii to be strongly dependent on the algal diets, implying differential assimilation, related either to cell characteristics such as presence of frustules or even to cell size, or, a combination of both.

Acknowledgements. This study was supported financially by the Commission of the European Community, through contract MAS3-CT95-0039 (TASC), and by the Plymouth Marine Laboratory. We thank the anonymous reviewers for their critical review that improved the manuscript.

\section{LITERATURE CITED}

Allan JD, Richman S, Heinle DR, Huff R (1977) Grazing in juvenile stages of some estuarine calanoid copepods. Mar Biol 43:317-331

Ban S, Burns C, Castel J, Chaudron Y, Christou E, Escribano R, Umani SF, Gasparini S, Ruiz FG, Hoffmeyer M, Ianora A, Kang HK, Laabir M, Lacoste A, Miralto A, Ning X, Poulet S, Rodriguez V, Runge J, Shi J, Starr M, Uye S, Wang Y (1997) The paradox of diatom-copepod interactions. Mar Ecol Prog Ser 157:287-293

Berggreen U, Hansen B, Kiørboe T (1988) Food size spectra, ingestion and growth of the copepod Acartia tonsa during development: implications for determination of copepod production. Mar Biol 99:341-352

Carlotti F, Krause M, Radach G (1993) Growth and development of Calanus finmarchicus related to the influence of temperature: experimental results and conceptual model. Limnol Oceanogr 38:1125-1134

Chaudron Y, Poulet SA, Laabir M, Ianora A, Miralto A (1996) Is hatching success of copepod eggs diatom densitydependent? Mar Ecol Prog Ser 144:185-193

Checkley DM (1980) The egg production of a marine planktonic copepod in relation to food supply: laboratory studies. Limnol Oceanogr 25:430-446
Corkett CJ, McLaren IA, Sévigny JM (1986) The rearing of marine copepods Calanus finmarchicus (Gunnerus), C. glacialis Jaschnov and C. hyperboreus Kroyer with comment on the equiproportional rule (Copepoda). Syllogeus 58:539-546

Deevey GB (1960) Relative effects of temperature and food on seasonal variations in length of marine copepods in some eastern American and western European waters. Bull Bingham Oceanogr Collec Yale Univ 17:54-86

Diel S, Klein Breteler WCM (1986) Growth and development of Calanus spp. (Copepoda) during spring phytoplankton succession in the North Sea. Mar Biol 91:85-92

Fernández F (1979a) Particle selection in the nauplius of Calanus pacificus. J Plankton Res 1:313-328

Fernández F (1979b) Nutrition studies in the nauplius larva of Calanus pacificus (Copepoda: Calanoida). Mar Biol 53: 131-147

Frost BW (1972) Effects of size and concentration of food particles on the feeding behavior of the marine planktonic copepod Calanus pacificus. Limnol Oceanogr 17:805-815

Green EP, Harris RP, Duncan A (1991) The naupliar development of marine calanoid copepods under high and low food conditions. Bull Plankton Soc Jpn Spec Vol:347-362

Green EP, Harris RP, Duncan A (1992) The production and ingestion of faecal pellets by nauplii of marine calanoid copepods. J Plankton Res 14:1631-1643

Guillard RRL (1975) Culture of phytoplankton for feeding marine invertebrates. In Smith WL, Chaney MH (eds) Culture of marine invertebrate animals. Plenum Publishing Corporation, New York, p 29-60

Guisande C, Harris RP (1995) Effect of total organic content of eggs on hatching success and naupliar survival in the copepod Calanus helgolandicus. Limnol Oceanogr 40(3): $476-482$

Hart RC (1990) Copepod post-embryonic durations: Pattern, conformity, and predictability. The realities of isochronal and equiproportional development, and trends in the copepodid-naupliar duration ratio. Hydrobiologia 206: 175-206

Hirche HJ (1980) The cultivation of Calanoides carinatus Krøyer (Copepoda: Calanoida) under different temperature and food conditions - with a description of eggs and nauplii. J mar biol Ass UK 60:115-125

Hirche HJ, Meyer U, Niehoff B (1997) Egg production of Calanus finmarchicus: effect of temperature, food and season. Mar Biol 127:609-620

Hitchcock GL (1982) A comparative study of the size-dependent organic composition of marine diatoms and dinoflagellates. J Plankton Res 4:363-377

Hopcroft RR, Roff JC (1998) Zooplankton growth rates: the influence of size in nauplii of tropical marine copepods. Mar Biol 132:87-96

Huntley ME, Lopez MDG (1992) Temperature-dependent production of marine copepods: a global synthesis. Am Nat 140:201-242

Ianora A, Poulet SA (1993) Egg viability in the copepod Temora stylifera. Limnol Oceanogr 38:1615-1626

Ianora A, Miralto A, Buttino I, Romano G, Poulet SA (1999) First evidence of some dinoflagellates reducing male copepod fertilization capacity. Limnol Oceanogr 44: 1476-153

Irigoien X, Head RN, Harris RP, Cummings D, Harbour D, Meyer-Harms B (2000a) Feeding selectivity and egg production of Calanus helgolandicus in the English Channel. Limnol Oceanogr 45:44-54

Irigoien X, Harris RP, Head RN, Harbour D (2000b) Effect of microplankton composition on the egg production rates of 
Calanus helgolandicus in the English Channel. Limnol Oceanogr (in press)

Jónasdóttir SH (1994) Effects of food quality on the reproductive success of Acartia tonsa and Acartia hudsonica: laboratory observations. Mar Biol 121:67-81

Jónasdóttir SH, Kiørboe T (1996) Copepod recruitment and food composition: do diatoms affect hatching success? Mar Biol 125:743-750

Jónasdóttir SH, Kiørboe T, Tang KW, John MSt, Visser AW, Saiz E, Dam HG (1998) Role in diatoms in copepod production: good, harmless or toxic? Mar Ecol Prog Ser 172: 305-308

Kiørboe T, Mohlenberg F, Riisgard HU (1985) In situ feeding rates of planktonic copepods: a comparison of four methods. J Exp Mar Biol Ecol 88:67-81

Klein Breteler WCM, Schogt N (1994) Development of Acartia clausi (Copepoda, Calanoida) cultured at different conditions of temperature and food. Hydrobiologia 292/293: 469-479

Klein Breteler WCM, Schogt N, Gonzalez SR (1990) On the role of food quality in grazing and development of life stages, and genetic change of body size during cultivation of pelagic copepods. J Exp Mar Biol Ecol 135:177-189

Klein Breteler WCM, Schogt N, Van der Meer J (1994) The duration of copepod life stages estimated from stage-frequency data. J Plankton Res 16:1039-1057

Koski M, Klein Breteler W, Schogt N (1998) Effect of food quality on rate of growth and development of the pelagic copepod Pseudocalanus elongatus (Copepoda, Calanoida). Mar Ecol Prog Ser 170:169-187

Laabir M, Poulet SA, Ianora A, Miralto A, Cueff A (1995) Reproductive response of Calanus helgolandicus. II. In situ inhibition of embryonic development. Mar Ecol Prog Ser 129:97-105

Laabir M, Poulet SA, Harris RP, Pond DW, Cueff A, Head RN, Ianora A (1998) Comparative study of the reproduction of Calanus helgolandicus in well-mixed and seasonally stratified coastal waters of the western English Channel J Plankton Res 20:407-421

Laabir M, Poulet SA, Cueff A, Ianora A (1999) Effect of diet on levels of amino acids during embryonic and naupliar development of the copepod Calanus helgolandicus. Mar Biol 134:89-98

Lopez MD (1991) Moulting and mortality depend on age and stage in naupliar Calanus pacificus: implication for development time of field cohorts. Mar Ecol Prog Ser 75:79-89

Lopez MD (1996) Effect of starvation on development and survivorship of naupliar Calanus pacificus (Brodsky). J Exp Mar Biol Ecol 203:133-146

Mayzaud P, Tirelli V, Bernard JM, Roche-Mayzaud O (1998) The influence of food quality on the nutritional acclimation of the copepod Acartia clausi. J Mar Sys 15:483-493

Melle W (1998) Reproduction, life cycles, and distribution of Calanus finmarchicus, C. glacialis and C. hyperboreus in relation to environmental conditions in the Barents Sea. Thesis for the partial fulfilment of the Doctor of Science degree. Department of Fisheries and Marine Biology, University of Bergen

Meyer-Harms B, Irigoien X, Head RN, Harris RP (1999) Selective feeding on natural phytoplankton by Calanus finmarchicus before, during and after the 1997 spring bloom in the Norwegian Sea. Limnol Oceanogr 44:154-165

Editorial responsibility: Otto Kinne (Editor), Oldendorf/Luhe, Germany
Mullin MM, Brooks R (1970) Growth and metabolism of two planktionic, marine copepods as influenced by temperature and type of food. University of California Press, Berkeley

Paffenhöfer GA (1970) Cultivation of Calanus helgolandicus under controlled conditions. Helgol Wiss Meeresunters 20:346-359

Paffenhöfer GA (1971) Grazing and ingestion rates of nauplii, copepodids and adults of the marine planktonic copepod Calanus helgolandicus. Mar Biol 11:286-298

Paffenhöfer GA (1976) Feeding, growth, and food conversion of the marine planktonic copepod Calanus helgolandicus Limnol Oceanogr 21:39-50

Pedersen G, Tande KS (1992) Physiological plasticity to temperature in Calanus finmarchicus. Reality or artefact? J Exp Mar Biol Ecol 155:183-197

Peterson WT (1986) Development, growth, and survivorship of the copepod Calanus marshallae in the laboratory. Mar Ecol Prog Ser 29:61-72

Peterson WT (1988) Rates of egg production by the copepod Calanus marshallae in the laboratory and in the sea off Oregon, USA. Mar Ecol Prog Ser 47:229-237

Peterson WT, Painting SJ (1990) Developmental rates of the copepods Calanus australis and Calanoides carinatus in the laboratory, with discussion of methods used for calculation of development time. J Plankton Res 12:283-293

Plourde S, Runge JA (1993) Reproduction of the planktonic copepod Calanus finmarchicus in the Lower St Lawrence Estuary: relation to the cycle of phytoplankton production and evidence for a Calanus pump. Mar Ecol Prog Ser 102: 217-227

Pond D, Harris R, Head R, Harbour D (1996) Environmental and nutritional factors determining seasonal variability in the fecundity and egg viability of Calanus helgolandicus in coastal waters off Plymouth, UK. Mar Ecol Prog Ser 143: $45-63$

Poulet SA, Ianora A, Miralto A, Meijer A (1994) Do diatoms arrest embryonic development in copepods? Mar Ecol Prog Ser 111:79-86

Poulet SA, Laabir M, Ianora A, Miralto A (1995) Reproductive response of Calanus helgolandicus. I. Abnormal embryonic and naupliar development. Mar Ecol Prog Ser 129: 85-95

Scherrer B (1984) Biostatistique. Gaëtan Morin, Québec

Støttrup JG, Jensen J (1990) Influence of algal diet on feeding and egg-production of the calanoid copepod Acartia tonsa Dana. J Exp Mar Biol Ecol 141:87-105

Thompson BM (1982) Growth and development of Pseudocalanus elongatus and Calanus sp. in the laboratory. J Mar Biol Ass UK 62:359-372

Verity PG, Smayda TJ (1989) Nutritional value of Phaeocystis pouchetii (Prymnesiophyceae) and other phytoplankton for Acartia spp. (Copepoda): ingestion, egg production, and growth of nauplii. Mar Biol 100:161-171

Vidal J (1980a) Physioecology of zooplankton. I. Effects of phytoplankton concentration, temperature, and body size on the growth rate of Calanus pacificus and Pseudocalanus sp. Mar Biol 56:111-134

Vidal J (1980b) Physioecology of zooplankton. II. Effects of phytoplankton concentration, temperature, and body size on the development and moulting rates of Calanus pacificus and Pseudocalanus sp. Mar Biol 56:135-146

Submitted: June 24, 1999; Accepted: November 8, 2000

Proofs received from author(s): May 30, 2001 